\title{
Earnings Management and Underpricing of Initial Public Offerings (IPO), Evidence from Iran
}

\author{
Gholamreza Karami ${ }^{1}$, Ali Ebrahimi Kordlar ${ }^{2}$, Yasin Amini $^{3} \&$ Saeed Hajipour ${ }^{3}$ \\ ${ }^{1}$ Associate Professor of Accounting, Faculty of Management, Tehran University, Tehran, Iran \\ ${ }^{2}$ Assistant Professor of Accounting, Faculty of Management, Tehran University, Tehran, Iran \\ ${ }^{3}$ M. A. Student of Accounting, Faculty of Management, Tehran University, Tehran, Iran \\ Correspondence: Yasin Amini, M. A. Student of Accounting, Faculty of Management, University of Tehran, \\ Pol-e-Nasr, Tehran, P. O. Box 14155-6311, Iran. Tel: 98-912-847-2336. E-mail: yasinamini@ut.ac.ir
}

Received: April 11, 2014

Accepted: April 28, 2014

Online Published: June 25, 2014

doi:10.5539/ibr.v7n7p156

URL: http://dx.doi.org/10.5539/ibr.v7n7p156

\begin{abstract}
The aim of this study is to answer an important but unanswered question about manipulation of earnings before initial public offerings. Several studies have examined earnings management in IPOs. In previous studies, researchers did not examine that firms manipulating income figures have seen little underpricing or confronted with larger underpricing despite aggressive earning management. We used somewhat new proxy of earnings management to test whether approximately high degree of earnings manipulation before IPO cause larger underpricing or not. This assertion is based on asymmetric information theory in underpricing literature that claims firms with approximately high degree of earnings manipulation have increased ex-ante uncertainty. As we know from research literature, increase in ex-ante uncertainty leads to steeper price discounts. However this is despite the prevailing hypothesis that firms going public can fool the market by offering higher prices for their shares. We did not find any significant relationship between earnings management and underpricing and thus our finding is consistent with the hypothesis that suggests high degree of earnings manipulation before going public leads to little underpricing.
\end{abstract}

Keywords: earnings management, Initial Public Offerings (IPO), underpricing

\section{Introduction}

Going public is one of the most common events that create an opportunity for management to offer higher prices for their firms by distorting income numbers. Several studies in research literature show evidences that firms manipulate earnings upwardly in this occasion (Friedlan, 1994; Teoh et al., 1998a, b; DuCharme et al., 2001, 2004). Also some studies show that discretionary accruals as a measure of earnings manipulation has a contradictory effect on long run return of these shares. This suggests that high degree of earnings manipulation is probably a strong reason for long run underperformance of IPO firms (Teoh et al., 1998b; DuCharme et al., 2001). On the other hand, there are some researches that show document inconsistent with the studies mentioned (Fan, 2007; Ball \& Shivakumar, 2008; Armstrong et al., 2009).

The mixed results suggest that managers have different incentives for managing earnings and therefore we should not expect to see equally same degree of earnings management during an IPO. And we think this cross company variation in the extent of earnings management is a major reason accounting for differences in extent of underpricing among firms going public.

There are little researches in previous works about the subject of this paper and this is main reason that led us to examine this relation. In prior researches there are mixed documents that came to competing results. Some of them show earnings management before IPO causes negative returns for IPO firms in long run. Also there is contrary evidences in the literature. For example opportunistic behavior of managers denote that firms with higher reported earnings are priced higher than firms not managing income numbers upwardly without consideration of their earnings quality that can be destroyed with this practice. Based on Beatty and Ritter (1986) proposition, underpricing has positive relationship with uncertainty about the price of IPO shares before initial offerings (Ljungqvist, 2007) (Note 1). The existing theory and empirical results in the literature suggest that shares with blurred earnings have little attraction for investors and they are not willing to pay higher prices for 
these shares. Thus, we can say managing earnings can lead to more ex-ante uncertainty about issuing firm and therefore causing more underpricing. Based on materials discussed above, we aim to examine the effect of earnings manipulation on the performance of shares in the short run period after public offering in Iranian stock exchanges.

Iranian IPOs, similar to other countries around the world, usually have incentives to manipulate income figures and thus our sample is suitable for the research purpose in explanation of differences in short run performance of IPO firms. Underlying reason to why firms going public have incentives to manipulate earnings is that by doing so they can gain competitive advantages against already listed firms that are bigger and more stable than new ones. Reduction of uncertainty as a result of manipulating earnings can further encourage this practice and can lead to high degree of earnings manipulation.

Using McNichols Model of earnings management (2002), this study is going to show whether high degree of earnings manipulation can help an IPO firm in meeting its objectives by decreasing underpricing or not. A positive association between aggressive earnings management and underpricing is not consistent with findings in the literature that show there is a strong association between earnings quality and ex-ante uncertainty surrounding an IPO firm that cause cross-company variations in underpricing. We expect that our results confirm the documents showing a positive association between distortion of income figures and increase of uncertainty before a public offerings. This is because worsening of earning (by manipulating of earnings) causes more uncertainty about IPO firm and thus investors pay fewer for these firms.

Prior efforts of researchers show considerable differences in the degree of earnings manipulation (for example, Teoh et al., 1998a, b for US IPOs; Ball \& Shivakumar, 2008 for UK IPOs). One of our objectives in conducting this study is to emphasize on the significance of looking into the reasons causing cross-sectional differences in the extent of earnings management in IPO firms and effects of them in forming stock prices. There is a great number of researches in IPO literature but we add to the literature because of the following reasons. First, in this study we are going to document a direct association between discretionary accruals and short run performance of IPO which little studies have extensively explored it. Further previous studies ignore the probability that manipulation of earnings can be cited as one of the reasons that explains underpricing. Second, in this study we study reasons accounting for inter firm differences in underpricing. IPO literature has emphasized mainly the significance of variation in distortion of income figures between IPO firms and other firms and has ignored the interfirm differences of IPO firms.

In this study section 2 discusses the prior literature and based on theories that discusses, provide research design about the related issues. Section 3 describes the characteristics of the Iranian IPO. Section 4 presents sample and descriptive statistics. Section 5 reports the empirical results, and Section 6 presents a summary and concluding remarks.

\section{Literature Review, Hypothesis Development and Research Design}

\subsection{Literature Review and Hypothesis Development}

Management has strong incentives to manage earnings during IPO because they want to reduce amount of underpricing with increasing reported earnings. So this event has been cited as a common occasion for manipulation of earnings. The results of studies in literature that examine opportunistic behavior of management have shown notable inconsistency which highlights the importance of this study in studying the causes and effects of earnings management. Several studies show a negative correlation between discretionary accruals as a measure of earnings management before and after going public and performance of these firms after this event. On the other hand there is some empirical results questioning this association (Fan, 2007; Ball \& Shivakumar, 2008; Armstrong et al., 2009).

There is an implicit assumption in prior studies that assumes higher prices for higher income numbers and they ignore earnings quality. But based on prominent theories of underpricing, there is a different prediction about performance of firms with blurred earning (because of managed earnings). Information asymmetry is one of these theories that has been provided by Ritter (1984) and were formalized in Beatty and Ritter (1986). They assert that underpricing should increase with increase in the ex-ante uncertainty on the value of the IPO firm. This is because the extent of the adverse selection problem is increasing because of ex-ante uncertainty around IPO firm and therefore investors has thus demanded more discounts to bid for their stocks (Ljungqvist, 2007; Rock, 1986). So we expect a direct association between blurred earnings and underpricing. Manipulation of earnings cause reported earnings to become blurred. Thus firms with extensive managed earnings have much ex-ante uncertainty about their firm value. So manipulation of income numbers can be cited as a significant reason accounting for differences in the extent of underpricing of IPOs. Justification of this explanation is based 
on earning quality literature that asserts stock price of firms with less blurred earnings are much higher than manipulating ones. For instance, documents show that there is significant positive association between country's overall earnings opacity and cost of equity in the stock market (Bhattacharya et al., 2003). This finding suggests that an increase in earnings management leads to increase in the cost of equity. There are studies in the literature that have conducted their research around this topic on international basis (Boulton et al., 2011). However different extent of earnings quality and their empirical results deserve further studies in examination with the variations in the extent of short run performance between IPO firms in the stock exchanges.

Based on asymmetric information theory we expect the more aggressively managed earnings cause the IPO shares to be more discounted. Therefore, we want to test the following hypothesis:

"There is significant statistical relationship between high degree of earnings management and underpricing of IPO firms"

\subsection{Research Design}

Here, we benefited from multivariate regressions to test the research hypothesis. As argued above, we expect a positive association between earnings manipulation proxy and underpricing because of the blurriness caused by manipulation practice that causes more uncertainty around firms.

\subsection{Estimation of Earnings Manipulation}

In this paper we are going to separate firms manipulating earnings from non-manipulating ones to find out whether low quality of earnings, caused by the manipulation of earnings, has led to more underpricing or not. In this study we identify high quality earnings when they faithfully represent the characteristics of the fundamental processes of the company so less blurred earnings is the ones with less discretionary accruals. Hypothesis behind this assertion is that although managers has less discretion over manipulating cash flow, they do this by manipulation of earning numbers through choosing accounting methods and adjusting their estimates. Thus, these items show management flexibility in reporting income numbers. There are several definitions of accruals in research literature. A common definition of literature assumes that accruals are difference between net income before extraordinary items and operating cash flow and specifically is as follows:

$$
T A=N I-C F O
$$

Where TA stands for total accruals, NI is net income before extraordinary items and the CFO is operating cash flow. This definition is consistent with the literature, starting from DeAngelo (1986), Healy (1985) and McNichols and Wilson (1988). The discretionary accrual represents opportunistic practice carried out for representing a better picture of the firm and thus inflating prices. Discretionary accrual is a measure to identify the existence of accounting manipulation by the detriment of the quality of earnings presented in financial reports. That is why the focus of the study is to identify the discretionary portion of accruals which is an evidence of managerial manipulation of earnings. Thus after calculating total accrual we need to separate accruals to discretionary and nondiscretionary parts. Discretionary accruals are difference between total accruals and nondiscretionary accruals. Nondiscretionary accruals are adjustments and estimations of financial information that determined by accrual accounting procedures that is related to working capital, financing and investing activities of firms. Accrual adjustments are made to show significant conditions of the company and to present properly the financial performance of firms. However these adjustments are consistent with national and international reporting rules. Several studies in research literature have examined approaches and calculation methods of discretionary accruals regarding responsibility and decisions made by board of directors. Studies in 1990s and so on like Dechow et al. (1995) took the method introduced by Jones (1991). In these studies first problem is to detect which portion of accruals is related to the performance level (and thus is non-discretionary) and which portion could be manipulated with management discretion (and thus is discretionary). Breaking down the accrual to discretionary and non-discretionary parts has been the interest of many researches in the literature. Jones (1991) relaxed the hypothesis that nondiscretionary accruals are constant overtime and has conducted her research to control the effects of change in economic conditions on nondiscretionary accruals. Jones assumes that revenues are not in management control. The drawback of Jones model is that she ignores that management can manipulate earnings by timing of credit sales. Aiming to eliminate this drawback, Dechow et al. (1995) subtract change in accounting receivables from change in sales that leads to the presentation of the Modified Jones Model (1995) that was extensively used in later researches. We need a model to find out the nondiscretionary part of accruals. So based on the issues discussed, we use McNichols Model (2002) to calculate coefficient of discretionary and nondiscretionary portions of accruals in the whole market and then use these coefficients to calculate discretionary and nondiscretionary portions of accruals in the IPO firms and thus use the result to test first research hypothesis. This model is as follows: 


$$
\begin{gathered}
A C C i, t / T A i, t-1=\alpha 0(C F O i, t-1 / T A i, t-1)+\alpha 1(C F O i, t / T A i, t-1)+\alpha 2(C F O i, t+1 / T A i, t-1)+ \\
\alpha 3((\triangle S i, t) / T A i, t-1)+\alpha 4(P P E i, t / T A i, t-1)+\varepsilon i, t
\end{gathered}
$$

Where ACC is total accruals calculated using equation (1), TAit-1 is the total assets of IPO before a year before going public. $\mathrm{CFO}_{\mathrm{i}, \mathrm{t}-1}, \mathrm{CFO}_{\mathrm{i}, \mathrm{t}}$ and $\mathrm{CFO}_{\mathrm{i}, \mathrm{t}+1}$ are operating cash flows a year before IPO, year of IPO and a year after IPO correspondingly. $\Delta \mathrm{S}_{\mathrm{i}, \mathrm{t}}$ stands for sales change, and $\mathrm{PPE}_{\mathrm{i}, \mathrm{t}}$ is Planet, Property and Equipment (gross) and $\varepsilon_{i, t}$ is other information not explained by the model. In above model, the set values in the right-hand side of equation equal nondiscretionary part of accruals. So to calculate the discretionary portion of total accruals we use residual of this model.

After calculating discretionary accruals, to test effect of earnings manipulation on underpricing, we use the performance-matched abnormal accrual model proposed by Kothari et al. (2005). They calculated abnormal accrual by subtracting residual of the model from the discretionary accrual of industry in which they operate. We used this method and calculated abnormal accrual by subtracting this item from median of discretionary accrual in each industry. Level of obtained number is indication of earnings manipulation degree of each firm. In the earnings management literature several accrual-based measures are extensively used as an earnings management measure. As the discretionary and nondiscretionary parts of accruals are unobservable, separation of measurement error and proxy error is difficult (McNichols \& Wilson, 1988). So we use another proxy for showing the degree of earnings management. As mentioned above, real earnings management with the usage of cash flow is difficult and thus it is a good performance measure. Firms that have negative operating cash flow usually have a negative net income and it is less probable to report in their income statement negative bottom line with the exception that their management manipulate earnings to show positive number. Thus we consider a firm reporting positive earnings without positive operating cash flow as a firm manipulating earnings. Thus our proxy is change of sign between operating cash flow and income number multiplied by abnormal discretionary accruals that were calculated above.

\section{Iranian IPOs}

In Iran there is a common idea of initial public offerings similar to other countries. This is because in other countries initial public offering means that new stocks are offered in stock markets. Similarly regarding 1969 amendment law of business in Iran, the initial stock market was created with permission to issue underwriting statements to the publicly held corporations. So new stock is referred to stocks that were initially offered in first market and already these stocks were not trading in the Tehran Securities Exchange (TSE). According to Principle 44 of the Iranian Constitution law most public companies of Iran should divest to private sectors. The median age of IPO firms in our sample is 112 months, which is almost the same as those in developed countries. For example in the United States the median age of IPOs is about 110 months. As well as most Iranian IPOs have adopted the auction method.

\section{Sample Selection and Descriptive Statistics}

\subsection{Selecting Sample}

An early information of sample firms is collected from the prospectus of Iranian firms that offered their shares during the year 2001 to 2011. Then we used financial data of firms that is available for the two years in the Tehran Securities Exchange (TSE) database before initial public offering and others have been excluded from the sample. Also we excluded banks, securities firms, and insurance firms from sample to avoid regulation-related distortion. 91 firms are identified and their characteristics are presented in Table 1.

\subsection{Descriptive Statistics}

We presented detailed information about the extent of underpricing in our sample in Table 1 by year and industry. In this study we use monthly underpricing of the IPOs to test research hypothesis. This is because of the limit imposed by legislative bodies on the variation of stock price that is limited to 4-5 percent of the previous day`s closing price. Based on IPO literature we calculated underpricing as the difference between the closing price of the share one month after the offering date and the price at which the share is offered, and then divided this amount by the offer price to obtain initial return. Then we estimated Market Adjusted Initial Return (MAIR) by adjusting initial return that we calculated before by the return of market index (TEPIX, index which is used for shares on TSE) in same period.

Statistical results show that in average underpricing is about 0.111 for study sample and median of underpricing is 0.074 which indicates a distribution that is left-skewed. We observed 16.9 and 15.7 percentage return in the 2005 and 2010 respectively. Also underpricing of 2009 is 1.8 percentage which is the least on in the study period. Information pictured at Panel B implicitly indicates the differences among firms in industries. For instance, the 
Manufacture of machinery and equipment industry has a high mean underpricing of 0.428 , whereas Manufacture of rubber and plastics products industry has a lower mean underpricing of 0.036 .

Table 1. Degree of underpricing

\begin{tabular}{|c|c|c|c|c|c|}
\hline \multicolumn{6}{|c|}{ Panel A: Underpricing by year } \\
\hline \multirow[t]{2}{*}{ Year } & \multicolumn{2}{|c|}{ Underpricing } & \multicolumn{2}{|c|}{ Market adjusted underpricing } & \multirow[b]{2}{*}{ Number } \\
\hline & Mean & Median & Mean & Median & \\
\hline 2001 & 0.074532 & 0.112059 & 0.029525 & 0.047769 & 5 \\
\hline 2002 & 0.081994 & 0.087071 & 0.078509 & 0.058453 & 8 \\
\hline 2003 & 0.129476 & 0.155818 & 0.028198 & 0.036043 & 25 \\
\hline 2004 & 0.134184 & 0.127915 & 0.106183 & 0.07564 & 13 \\
\hline 2005 & 0.210516 & 0.176767 & 0.279228 & 0.169951 & 8 \\
\hline 2006 & 0.048437 & 0.050212 & 0.049712 & 0.051026 & 2 \\
\hline 2007 & 0.070325 & 0.113758 & 0.035724 & 0.056493 & 4 \\
\hline 2008 & 0.178098 & 0.214577 & 0.12781 & 0.094134 & 4 \\
\hline 2009 & 0.142857 & 0.057306 & 0.095844 & 0.018462 & 4 \\
\hline 2010 & 0.372191 & 0.18117 & 0.319962 & 0.157411 & 5 \\
\hline 2011 & 0.120086 & 0.062438 & 0.118704 & 0.063143 & 13 \\
\hline Total & 0.139026 & 0.12050 & 0.111706 & 0.074377 & 91 \\
\hline
\end{tabular}

\begin{tabular}{|c|c|c|c|c|c|}
\hline \multicolumn{6}{|l|}{ Panel B: Underpricing by industry } \\
\hline \multirow{2}{*}{ Industry } & \multicolumn{2}{|c|}{ MAIR } & \multirow{2}{*}{ Industry } & \multicolumn{2}{|c|}{ MAIR } \\
\hline & Mean & Number & & Mean & Number \\
\hline Chemical products & 0.145053 & 10 & $\begin{array}{l}\text { Manufacture of other non-metallic } \\
\text { mineral products }\end{array}$ & 0.106908 & 5 \\
\hline $\begin{array}{l}\text { Manufacture of motor vehicles, trailers } \\
\text { and semi-trailers }\end{array}$ & 0.05131 & 6 & $\begin{array}{l}\text { Manufacture of radio, television and } \\
\text { communication equipment and } \\
\text { apparatus }\end{array}$ & -0.05941 & 1 \\
\hline Manufacture of basic metals & 0.106239 & 10 & Land transport; transport via pipelines & -0.11397 & 5 \\
\hline Food \& Beverage except sugar & 0.114439 & 4 & $\begin{array}{l}\text { Manufacture of coke, refined } \\
\text { petroleum products and nuclear fuel }\end{array}$ & -0.01804 & 3 \\
\hline Pharmacy & 0.04115 & 5 & $\begin{array}{l}\text { Manufacture of machinery and } \\
\text { equipment }\end{array}$ & 0.428577 & 2 \\
\hline Real estate activities & 0.156581 & 5 & $\begin{array}{l}\text { Mining of coal and lignite; extraction } \\
\text { of peat }\end{array}$ & -0.05657 & 1 \\
\hline $\begin{array}{l}\text { Manufacture of rubber and plastics } \\
\text { products }\end{array}$ & 0.036032 & 3 & $\begin{array}{l}\text { Manufacture of fabricated metal } \\
\text { products, except machinery and } \\
\text { equipment }\end{array}$ & 0.053181 & 1 \\
\hline Mining of metal ores & 0.214409 & 3 & Other business activities & 0.112987 & 1 \\
\hline $\begin{array}{l}\text { Manufacture of medical, precision and } \\
\text { optical instruments, watches and clocks }\end{array}$ & 0.085445 & 2 & Telecommunication & 0.353313 & 1 \\
\hline Computer and related activities & 0.388034 & 6 & $\begin{array}{l}\text { Oil and Gas Exploration and auxiliary } \\
\text { services other than discovery }\end{array}$ & 0.425988 & 1 \\
\hline $\begin{array}{l}\text { Manufacture of electrical machinery and } \\
\text { apparatus }\end{array}$ & -0.16943 & 3 & Construction & 1.40514 & 1 \\
\hline Cement, lime and plaster & -0.00562 & 11 & Sugar & 0.341798 & 1 \\
\hline
\end{tabular}




\section{Empirical Analyses}

Following to test research hypothesis, we used regression analysis in examination of the effect that manipulation of earnings may has on the underpricing. In so doing, based on research literature we control the effects of variables accounting for the extent of underpricing (indexes have been omitted):

$$
\begin{gathered}
\text { MAIR }=\alpha 0+\alpha 1 \text { Earnings management metric }+\alpha 2 \text { Industry }+\alpha 3 \text { Size }+\alpha 4 \text { Age }+ \\
\alpha 5 \text { Growth }+\alpha 6 \text { Market }+\varepsilon
\end{gathered}
$$

MAIR denotes Market Adjusted Initial Return, our dependent variable that were calculated as before. Earnings management metric is ABSAAC multiplied by sing change, the key variables that capture the degree of earnings management. AAC and SIGNCH, calculated as before. Note that ABSAAC stands for the absolute value of AAC. The interaction of ABSAAC and Sign change is included as an alternative to AAC as ABSAAC multiplied by sign change represents firms that are suspected of manipulation of earnings. Then another control variable that we use includes Industry, a dummy variable that takes 1 if a firm is in the Manufacture of Machinery and Equipment industry and 0 otherwise. We included this variable because based on statistical result shown above, the Manufacture of Machinery and Equipment industry has higher initial return than other industries. Size is another controlling variable which is equal to the natural logarithm of sales revenues. Age equals to the time length from firm establishment and we expect to see a negative sign for this variable. The growth of sales before IPO is indicated by Growth. And finally Market is a dummy variable that takes the value 1 if the firm went public during hot markets and 0 otherwise. As shown in the descriptive statistics section, abnormally high first month returns are observed in 2005, 2008, and 2010.

Table 2 shows the results of the multivariate regression. Our main variable to observe is Earnings Management Metric. In the conditions of having high degree of manipulating income numbers that we expect to increase the uncertainty about IPOs and high degree of monitoring on the firms want to go public, higher degree of earnings manipulation could lead more underpricing. Results show that despite the hypothesis, the coefficient of this variable is positive but statistically not significant at the $1 \%$ level. These results do not confirm that aggressive earnings management leads to a larger discount in the offer price.

Based on study results we did not find any significant relationship between high degree of earnings manipulation and underpricing of our sample firms. This shows that managers that manipulate earnings can fool the market without increasing the uncertainty about their firms and their do not have more initial returns after being offered to the public in comparison to non-manipulating ones.

\begin{tabular}{|c|c|c|c|c|}
\hline \multicolumn{5}{|c|}{ MAIR $=\alpha_{0}+\alpha_{1}$ Earnings management metric $+\alpha_{2}$ Industry $+\alpha_{3}$ Size $+\alpha_{4}$ Age $+\alpha_{5}$ Growth $+\alpha_{6}$ Market $+\varepsilon$} \\
\hline Variable & Coefficient & Standard Error & T-Statistic & Probability \\
\hline Intercept & 0.130470 & 0.217656 & 0.599429 & 0.5506 \\
\hline Earnings management Metric & 0.007650 & 0.109659 & 0.069759 & 0.9446 \\
\hline Industry & 0.564322 & 0.133927 & 4.213654 & 0.0001 \\
\hline Size & -0.002306 & 0.016934 & -0.136160 & 0.8920 \\
\hline Age & -0.000740 & 0.002535 & -0.291778 & 0.7712 \\
\hline Growth & -1.00007 & 6.000063 & -0.256018 & 0.7986 \\
\hline Market & 0.050435 & 0.059560 & 0.846788 & 0.3997 \\
\hline R-squared & 0.194987 & \multicolumn{2}{|c|}{ Adjusted R-squared } & 0.133847 \\
\hline Mean dependent variable & 0.133578 & \multicolumn{2}{|c|}{ Durbin Watson Statistic } & 1.662877 \\
\hline F-Statistic & 3.189179 & \multicolumn{2}{|c|}{ F-Statistic } & 0.007439 \\
\hline
\end{tabular}

Table 2. Empirical results

\section{Summary and Concluding Remarks}

In this paper we studied a significant but unanswered problem in research literature that by how extent does earnings management affect underpricing. Prior studies extensively have examined the underpricing. Despite the importance of underpricing in the literature of IPO and earnings management, few studies examined association between high degree of earnings manipulation and underpricing. We also used a new proxy for manipulation of 
earnings. We did not find that high degree of earnings manipulation causes more underpricing of firms going public. This finding is consistent with the previous findings in the research literature that manipulation of earnings enables managers to fool the market by offering higher offer prices for their firm. These findings suggest that differences in the extent of earnings management do not cause cross-company variations in underpricing. Contrary to the asymmetric information theory, the results of this study show that investors overvalue firms with lower earnings quality.

In our study we did not examine the possibility that whether investors are able to detect firms with aggressive earnings management from others or not. In this regard, we propose that future research examine other time periods of underpricing to find out whether the same results hold. Because of mixed results that we discussed them above, we propose the replication of this topic using new measures of earnings management and in other stock markets.

\section{Acknowledgments}

The authors wish to thank Kamran Tajik and Salman Beik Boshrouyeh for suggestions on preparing the manuscript and their most support and encouragement. They kindly read our paper and offered invaluable detailed advices on grammar, organization, and the theme of the paper.

\section{References}

Armstrong, C. S., Foster, G., \& Taylor, D. J. (2009). Earnings management around initial public offerings: a re-examination. Working Paper. http://dx.doi.org/10.2139/ssrn.1147328

Ball, R., \& Shivakumar, L. (2008). Earnings quality at initial public offerings. Journal of Accounting and Economics, 45, 324-349. http://dx.doi.org/10.2139/ssrn.918421

Beatty, R. P., \& Ritter, J. R. (1986). Investment banking, reputation, and the underpricing of initial public $\begin{array}{lllll}\text { offerings. Journal of Finance and Economics, 15, 232. } & \text { 213 }\end{array}$ http://dx.doi.org/10.1016/0304-405X(86)90055-3

Bhattacharya, U., Daouk, H., \& Welker, M. (2003). The world price of earnings opacity. Accounting Review, 78. http://dx.doi.org/10.2139/ssrn.282117

Boulton, T. J., Smart, S. B., \& Zutter, C. J. (2011). Earnings quality and international IPO underpricing. Accounting Review, 86, 483-505. http://dx.doi.org/10.2308/accr.00000018

DeAngelo, L. E. (1986). Accounting numbers as market valuation substitutes: A study of management buyouts of public stockholders. Accounting Review, 400-420.

Dechow, P. M., Sloan, R. G., \& Sweeney, A. P. (1995). Detecting earnings management. Accounting Review, 193-225.

DuCharme, L. L., Malatesta, P. H., \& Sefcik, S. E. (2001). Earnings management: IPO valuation and subsequent performance. Journal of Accounting, Auditing and Finance, 16, 369-396.

DuCharme, L. L., Malatesta, P. H., \& Sefcik, S. E. (2004). Earnings management, stock issues, and shareholder $\begin{array}{lllll}\text { lawsuits. Journal of Finance and } & \text { Economics, }\end{array}$ http://dx.doi.org/10.1016/S0304-405X(03)00182-X

Fan, Q. (2007). Earnings management and ownership retention for initial public offering firms: theory and evidence. Accounting Review, 82, 27-64. http://dx.doi.org/10.2308/accr.2007.82.1.27

Friedlan, J. M. (1994). Accounting choices of issuers of initial public offerings. Contemporary Accounting Researches, 11, 1-31. http://dx.doi.org/10.1111/j.1911-3846.1994.tb00434.x

Healy, P. M. (1985). The effect of bonus schemes on accounting decisions. Journal of Accounting and Economics, 7(1). http://dx.doi.org/10.1016/0165-4101(85)90029-1

Jones, J. (1991). Earnings management during import relief investigations. Journal of Accounting Research, 29(2). http://dx.doi.org/10.2307/2491047

Kothari, S., Leone, A., \& Wasley, C. (2005). Performance matched discretionary accrual measures. Journal of Accounting and Economics, 39, 163-197. http://dx.doi.org/10.2139/ssrn.264859

Ljungqvist, A. (2007). IPO underpricing. In Eckbo, B. E. (Ed.), Handbook of Corporate Finance, Empirical Corporate Finance (pp. 375-722). North-Holland: Elsevier. http://dx.doi.org/10.1016/B978-0-444-53265-7.50021-4

McNichols, M. F. (2002). Discussion of the quality of accruals and earnings: The role of accrual estimation 
errors. Accounting Review, 77(s-1), 61-69. http://dx.doi.org/10.2308/accr.2002.77.s-1.61

McNichols, M., \& Wilson, G. P. (1988). Evidence of earnings management from the provision for bad debts. Journal of Accounting Researches, 26, 1-31. http://dx.doi.org/10.2307/2491176

Nagata, K., \& Makino, H. (2012). Earnings quality and valuation of IPOs. Japan Journal of Finance, 32, 77-90.

Ritter, J. R. (1984). The 'Hot Issue' market of 1980. Journal of Business, 57, 215-240. http://dx.doi.org/10.1086/296260

Ritter, J. R., \& Welch, I. (2002). A review of IPO activity, pricing, and allocations. Journal of Finance, 57, 1795-1828. http://dx.doi.org/10.1111/1540-6261.00478

Rock, K. (1986). Why new issues are underpriced. Journal of Finance and Economics, 15, 187-212. http://dx.doi.org/10.1016/0304-405X(86)90054-1

Teoh, S. H., Welch, I., \& Wong, T. J. (1998b). Earnings management and the long-run market performance of initial public offerings. Journal of Finance, 53, 1935-1974. http://dx.doi.org/10.1111/0022-1082.00079

Teoh, S. H., Wong, T. J., \& Rao, G. R. (1998a). Are accruals during initial public offerings opportunistic? Review of Accounting Studies, 3, 175-208. http://dx.doi.org/10.1023/A:1009688619882

\section{Note}

Note 1 . Underpricing is usually measured as the percentage difference between the offer price and the closing market price of the first day of trading. In this we used the term underpricing, initial return and short run performance of IPO shares interchangeably.

\section{Copyrights}

Copyright for this article is retained by the author(s), with first publication rights granted to the journal.

This is an open-access article distributed under the terms and conditions of the Creative Commons Attribution license (http://creativecommons.org/licenses/by/3.0/). 